\title{
NGNP Component Test Capability Design Code of Record
}

S. L. Austad

D. S. Ferguson

L. E. Guillen

C. W. McKnight

P. J. Petersen

September 2009
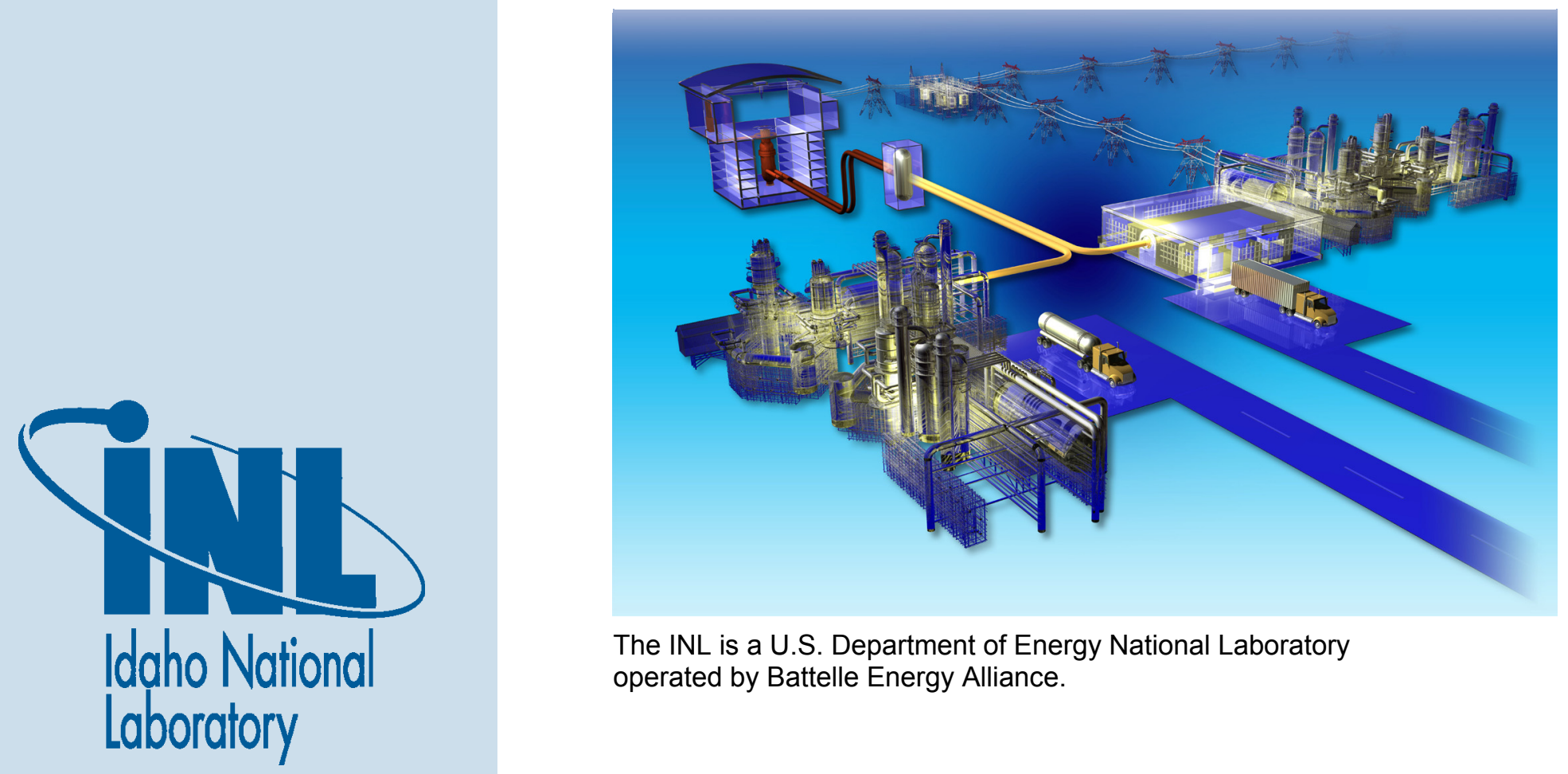

The INL is a U.S. Department of Energy National Laboratory operated by Battelle Energy Alliance. 


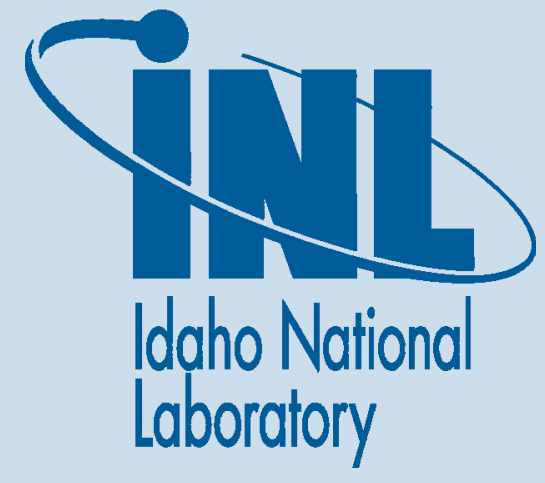

The INL is a U.S. Department of Energy National Laboratory operated by Battelle Energy Alliance. 


\section{DISCLAIMER}

This information was prepared as an account of work sponsored by an agency of the U.S. Government. Neither the U.S. Government nor any agency thereof, nor any of their employees, makes any warranty, expressed or implied, or assumes any legal liability or responsibility for the accuracy, completeness, or usefulness, of any information, apparatus, product, or process disclosed, or represents that its use would not infringe privately owned rights. References herein to any specific commercial product, process, or service by trade name, trade mark, manufacturer, or otherwise, does not necessarily constitute or imply its endorsement, recommendation, or favoring by the U.S. Government or any agency thereof. The views and opinions of authors expressed herein do not necessarily state or reflect those of the U.S. Government or any agency thereof. 


\title{
NGNP Component Test Capability Design Code of Record
}

\author{
S. L. Austad \\ D. S. Ferguson \\ L. E. Guillen \\ C. W. McKnight \\ P. J. Petersen \\ September 2009 \\ Idaho National Laboratory \\ Next Generation Nuclear Plant Project \\ Idaho Falls, Idaho 83415 \\ Prepared for the \\ U.S. Department of Energy \\ Office of Nuclear Energy \\ Under DOE Idaho Operations Office \\ Contract DE-AC07-05ID14517
}



Next Generation Nuclear Plant Project

\section{NGNP Component Test Capability Design Code of Record}

INL/EXT-09-16702

September 2009

Approved by:

S.L. Austad, P.E.

Date

F\&SS Project Lead

V.J. Balls, P.E.

CTC Project Engineer

Date

V.F. Tonc

Date

CTC Project Manager 



\begin{abstract}
The Next Generation Nuclear Plant Project is conducting a trade study to select a preferred approach for establishing a capability whereby NGNP technology development testing - through large-scale, integrated tests - can be performed for critical HTGR structures, systems, and components (SSCs). The mission of this capability includes enabling the validation of interfaces, interactions, and performance for critical systems and components prior to installation in the NGNP prototype. The four alternatives being evaluated in the NGNP trade study to validate the interfaces and performance of critical systems and components prior to installation in the NGNP prototype are described in this report. The Design Code of Record for each alternative will vary, depending on the final location (jurisdiction) of the capability upgrades or facilities. This report describes the alternatives under consideration for providing the HTGR CTC and the Code of Record strategy for each.
\end{abstract}




\section{CONTENTS}

ABSTRACT. vi

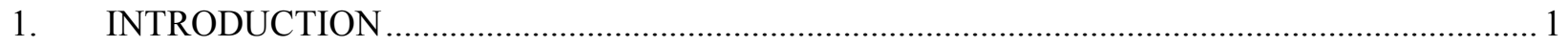

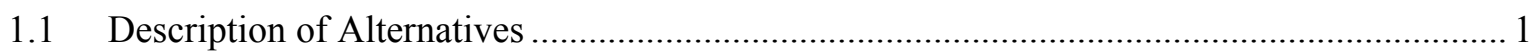

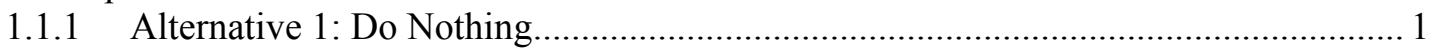

1.1.2 Alternative 2: Vendor Distributed Testing............................................................ 2

1.1.3 Alternative 3: Modification of Existing Facilities ............................................... 2

1.1.4 Alternative 4: Single, Standalone Component Test Facility ...................................... 3

2. REGULATIONS, EXECUTIVE ORDERS, DOE ORDERS …............................................. 3

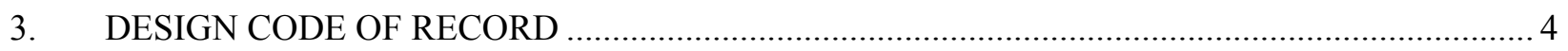

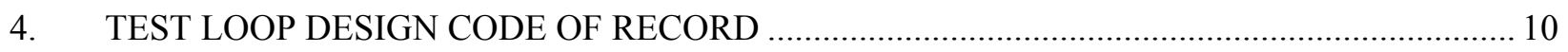

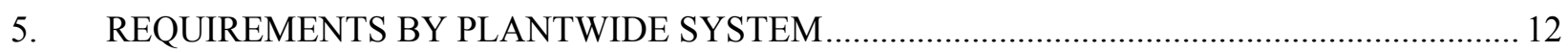




\section{NGNP Component Test Capability Design Code of Record}

\section{INTRODUCTION}

The Next Generation Nuclear Plant (NGNP) Project is conducting a trade study to select a preferred approach for establishing a component test capability (CTC) whereby NGNP technology development testing - from material tests up through large-scale, integrated tests - can be performed for critical high temperature gas-cooled reactor (HTGR) structures, systems, and components (SSCs). The mission of this CTC includes enabling the validation of interfaces, interactions, and performance for critical systems and components prior to installation in the NGNP prototype.

Four alternatives are being evaluated in the NGNP trade study. Each of the alternatives is linked to a distinct approach for addressing NGNP technical risk. The alternatives for completing the large-scale integrated testing necessary to validate the interfaces and performance of critical systems and components prior to installation in the NGNP prototype include:

1. Do nothing - no large-scale testing of NGNP critical SSCs

2. Distribute the testing requirements to the component and system vendors as part of the specifications for procurement

3. Modify existing facilities (mostly overseas) to support NGNP large-scale testing needs

4. Construct a stand-alone facility to house and operate test loops designed to meet NGNP large-scale testing needs.

The Design Code of Record for each alternative will vary depending on the final location (jurisdiction) of the capability upgrades or facilities. The following subsections describe the alternatives under consideration for providing the HTGR CTC and the Code of Record strategy for each. Sections 2 and 3 provide typical U.S. facility and test loop code requirements, assuming the facility is a Department of Energy (DOE)-owned user facility.

\subsection{Description of Alternatives}

\subsubsection{Alternative 1: Do Nothing}

Alternative 1 reflects the NGNP Project adopting a risk acceptance response strategy for the technology risks associated with critical HTGR SSCs. Under this alternative, no technology development or large-scale testing of critical SSCs will be performed except for integration testing conducted during cold start-up activities for the NGNP prototype. The NGNP design team will be responsible for all SSC engineering and for producing all designs and specifications for the prototype's SSCs.

Prescriptive specifications will be issued by the NGNP Project to vendors who build the SSCs per those specifications. The completed SSCs will then be shipped to the NGNP prototype where they will be evaluated for acceptance and installed in the prototype reactor. The NGNP Project will retain liability for the SSCs' reliability, operability, etc., and any defects will have to be addressed and repaired (or replaced) during start-up or hot operations.

This alternative will rely on the code of record for the NGNP. No additional CTC Code of Record will be required. 


\subsubsection{Alternative 2: Vendor Distributed Testing}

This alternative reflects the NGNP Project adopting a "risk transfer" response strategy to reduce the technology risks associated with critical HTGR SSCs. Under this alternative, risk and technology development associated with critical SSCs' materials of construction, performance, safety, and operation will be transferred to the vendor using performance specifications. The vendors, in conjunction with the NGNP, will decide the amount, types, and levels of material and technology development testing that they will perform to meet the NGNP performance specifications. Vendors will fund any modification or construction of test capabilities that they need to manage their liabilities and support their development and testing plans relative to their SSCs. It is expected that the vendors will amortize any test capability implementation costs they incur as part of their SSC bid price. Then, as in Alternative 1, the NGNP Project will perform integrated testing of the critical SSCs as part of cold start-up and hot operation activities for the NGNP prototype.

\subsubsection{Alternative 3: Modification of Existing Facilities}

\subsubsection{Alternative 3A: Overseas Testing Facilities}

This alternative reflects the NGNP Project adopting a "risk reduction" response strategy to address the technology risks associated with critical HTGR SSCs. Under this alternative, one or more existing facilities will be utilized to the fullest extent possible to support material and technology development, large-scale, and, possibly, integration testing for critical HTGR SSCs. Technologies to be tested could be those proposed by vendors or those developed by vendors to meet NGNP designs and specifications. Existing facilities under consideration include:

1. Pebble Bed Modular Reactor facilities in the Republic of South Africa, where test loops could be designed and installed at either the High Temperature Helium Test Facility or in a new facility.

2. Afrikantov Experimental Machine Building Design Bureau (OKBM) facilities in Russia, where test loops could be designed and installed at the Russian Large Scale High Temperature Helium Test Facility. These facilities were built in the 1970s and operated into the 1980s. They have been deactivated and placed in a prolonged storage state since that time.

3. AREVA High Temperature Test facilities located in France. There are a number of existing facilities located in France that are used in the development of the AREVA "ANTARES" High Temperature Gas Reactor.

This alternative can be implemented in several different ways relying on vastly different contracting strategies. Two of the options under investigation are:

- Procure testing "services" from the "user" facility. This case has already been tested with NGNP research and development (R\&D) testing performed at university facilities.

- DOE becoming a "partner" or "leaser" in an upgraded "user" facility while retaining some ownership in the capital investment.

If this alternative is selected, extensive research will be performed on the codes and standards in effect in the selected country. Equivalence, gaps, and Nuclear Regulatory Commission quality requirements will be addressed and final design codes selected during the requirements definition phase.

\subsubsection{Alternative 3B: Domestic Testing Facilities}

This alternative reflects the NGNP Project adopting a "risk reduction" response strategy to address the technology risks associated with critical HTGR SSCs. Under this alternative, one or more existing 
domestic facilities will be utilized to the fullest extent possible to support material and technology development, large-scale, and, possibly, integration testing for critical HTGR SSCs. Technologies to be tested could be those proposed by vendors or those developed by vendors to meet NGNP designs and specifications. Facilities investigated would include both existing commercial and government-sector facilities.

This alternative can be implemented in several different ways relying on vastly different contracting strategies. Two of the options under investigation are:

- Procure testing "services" from the "user" facility. This case has already been tested with NGNP R\&D testing performed at university facilities.

- DOE becoming a "partner" or "leaser" in an upgraded "user" facility while retaining some ownership in the capital investment.

This alternative will be designed to the codes and standards in use in the local jurisdiction where the CTC loops and facility modifications will be constructed.

\subsubsection{Alternative 4: Single, Standalone Component Test Facility}

This alternative also reflects the NGNP Project adopting a "risk reduction" response strategy to address the technology risks associated with critical HTGR SSCs without introducing the residual risks associated with Alternative 3. In this alternative, a single, standalone facility will be constructed to house and operate test loops designed to meet NGNP material and technology development and large-scale testing needs for the HTGR prototype. The test facility, including any supporting utilities, will be constructed in the United States, where it will be fully-funded, owned, and operated by DOE or its representatives. After startup, the CTF could be used to test both NGNP-designed as well as vendorproposed SSCs. As an added advantage, the CTF will be designed and available for Advanced Energy Programs as a National Scientific User Facility, following the accomplishment of NGNP SSC testing scope, for ongoing HTGR component development testing and qualification and other high-temperature R\&D.

This alternative will use U.S.-based codes and standards with provisions for local jurisdictional requirements based on the final location of the CTF.

\section{REGULATIONS, EXECUTIVE ORDERS, DOE ORDERS}

Applicable regulations, executive orders, and DOE orders are summarized below. Codes marked with an asterisk $\left(^{*}\right)$ denote codes based on an Idaho location which may change if the CTC were located in another jurisdiction.

- Regulations:

- $\quad 10$ CFR 1910

- $\quad 10$ CFR 1926

- $\quad 10$ CFR 434 , Energy Conservation Voluntary Performance Standards for New Buildings; Mandatory for Federal Buildings

- *IDAPA 07.02.06, "Rules Concerning Uniform Plumbing Code," Division of Building Safety

- *IDAPA 58.01.16, "Wastewater Rules," State of Idaho Department of Environmental Quality

- *IDAPA 58.01.08 , "Idaho Rules For Public Drinking Water Systems," State of Idaho Department of Environmental Quality

- *IDAPA 58.01.08, "Idaho Rules For Public Drinking Water Systems," State of Idaho Department of Environmental Quality 
- $\quad$ *IDAPA 07.07.01, Rules Governing Installation Of Heating, Ventilation, and Air Conditioning Systems, Division of Building Safety

- DOE Orders:

- $\quad$ DOE O 420.1B, Facility Safety

- DOE O 430.2B, Departmental Energy, Renewable Energy and Transportation Management

- Other:

- *INL-STD-139, INL Engineering Standards

\section{DESIGN CODE OF RECORD}

The CTC conceptual design criteria for any U.S. facility modifications or new construction are summarized below. The Code of Record will be reviewed at the start of preliminary design to assess required updates or changes. Codes marked with an asterisk (*) denote codes based on an Idaho location which may change if the CTC were located in another jurisdiction.

- General Design:

- IBC, International Building Code 2009 Edition

- $\quad$ NFPA 101, Life Safety Code 2009 Edition

- IMC, International Mechanical Code 2009 Edition

- $\quad$ NFPA 70, National Electric Code (NEC)

- $\quad$ *INL-STD-139, INL Engineering Standards

- Civil, Structural, Architectural:

- SSHC, *State of Idaho Transportation Department, Division of Highways, Standard Specifications for Highway Construction

- Union Pacific Railroad, Technical Specifications for Industrial Tracks

- $\quad$ DOE O 420.1B, Facility Safety

- DOE-STD-1020, Natural Phenomena Hazards Design and Evaluation Criteria for Department of Energy Facilities

- $\quad$ *INL Welding Manual

- IBC, International Building Code 2009 Edition

- $\quad$ ASCE 7, Minimum Design Loads for Buildings and other Structures, American Society of Civil Engineers 2005 Edition

- $\quad$ ACI 318, Building Code Requirements for Structural Concrete, American Concrete Institute 2005 Edition

- $\quad$ ACI 530, Building Code Requirements for Masonry Structures, American Concrete Institute 2008 Edition

- ACI 530.1, Specifications for Masonry Structures, American Concrete Institute 2008 Edition

- $\quad$ AISC SCM, Steel Construction Manual, American Institute of Steel Construction $13^{\text {th }}$ Edition

- $\quad$ AISC 360, Specification for Structural Steel Buildings, American Institute of Steel Construction 2005 Edition

- AISI S100-S214, North American Specification for the Design of Cold-formed Steel Structural Members, American Iron and Steel Institute 2007 Edition

- $\quad$ ANSI/NC 1.0, Standard for Noncomposite Steel Floor Deck, Steel Deck Institute 2006 Edition 
- $\quad$ ANSI/RD 1.0, Standard for Steel Roof Deck, Steel Deck Institute 2006 Edition

- ASCE 5, Building Code Requirements for Masonry Structures, American Society of Civil Engineers 2008 Edition

- $\quad$ ASCE 6, Specifications for Masonry Structures, American Society of Civil Engineers 2008 Edition

- $\quad$ ASCE 8, Standard Specification for the Design of Cold-formed Stainless Steel Structural Members, American Society of Civil Engineers 2002 Edition

- ASME NOG-1, Rules for Construction of Overhead and Gantry Cranes (Top Running Bridge, Multiple Girder), American Society of Mechanical Engineers 2004 Edition

- $\quad$ AWS D1.1, Structural Welding Code - Steel, American Welding Society 2004 Edition

- $\quad$ AWS D1.3, Structural Welding Code - Sheet Steel, American Welding Society 1998 Edition

- $\quad$ AWS D1.4, Structural Welding Code - Reinforcing Steel, American Welding Society 1998 Edition

- $\quad$ SJI-CJ-1.0, Standard Specification for Composite Steel Joists, CJ-series, Steel Joist Institute 2006 Edition

- SJI-JG-1.1, Standard Specification for Joist Girders, Steel Joist Institute 2005 Edition

- SJI-K-1.1, Standard Specification for Open Web Steel Joists, K-series 2005 Edition

- $\quad$ SJI-LH/DLH-1.1, Standard Specification for Longspan Steel Joists, LH-series and Deep Longspan Steel Joists, DLH-series, Steel Joist Institute 2005 Edition

- Mechanical, HVAC, Piping:

- Energy Conservation:

- DOE O 430.2A, Departmental Energy and Utilities

- 10 CFR 434, Energy Conservation Voluntary Performance Standards for New Buildings; Mandatory for Federal Buildings

- ASHRAE 90.1, ANSI/ASHRAE/IESNA Standard 90.1-2004, Energy Standard for Buildings Except Low-Rise Residential Buildings.

- Building Service Piping:

- ASME B31.9, Building Service Piping

- *IDAPA 07.02.06, "Rules Concerning Uniform Plumbing Code” Division of Building Safety

- *IDAPA 58.01.16, "Wastewater Rules" State of Idaho Department of Environmental Quality

- *IDAPA 58.01.08, Idaho Rules for Public Drinking Water Systems" State of Idaho Department of Environmental Quality

- *IDAPA 07.07.01, "Rules Governing Installation of Heating, Ventilation, and Air Conditioning Systems" State of Idaho Division of Building Safety

- Cooling Towers:

- ASME B31.1, Power Piping, American Society of Mechanical Engineers 2007 Edition

- ASME B31.3, Process Piping, American Society of Mechanical Engineers 2008 Edition

- BPVC, Section I, Boiler Pressure Vessel Code - Power Boilers, American Society of Mechanical Engineers 2007 Edition

- BPVC, Section II, Boiler Pressure Vessel Code - Materials, American Society of Mechanical Engineers 2007 Edition 
- BPVC, Section IV, Boiler Pressure Vessel Code - Heating Boilers, American Society of Mechanical Engineers 2007 Edition

- BPVC, Section V, Boiler Pressure Vessel Code - Nondestructive Examination, American Society of Mechanical Engineers 2007 Edition

- BPVC, Section VIII, Boiler Pressure Vessel Code - Pressure Vessels, American Society of Mechanical Engineers 2007 Edition

- Tanks \& Utility Distribution:

- AWWA D100, Welded Carbon Steel Tanks for Water Storage, American Water Works Association 2005 Edition with 2007 Errata

- NACE SP0169, Control of External Corrosion on Underground or Submerged Metallic Piping Systems National Association of Corrosion Engineers 2007 Edition

- Potable Water and Sewer:

- *IDAPA 58.01.08, "Idaho Rules for Public Drinking Water Systems" State of Idaho Department of Environmental Quality

- Memorandum of Understanding (MOU) between the Idaho Department of Environmental Quality and the Idaho Division of Building Safety Plumbing Bureau, April 2003

- HVAC and Ducting:

- ASHRAE 90.1, Energy Standard for Buildings Except Low-Rise Residential Buildings

- ASHRAE 62, Ventilation for Acceptable Indoor Air Quality.

- NFPA 90A, Standard for the Installation of Air Conditioning and Ventilating Systems.

- NFPA 90B, Standard for the Installation of Warm Air Heating and Air Conditioning Systems.

- *IDAPA 07.07.01, Rules Governing Installation of Heating, Ventilation, and Air Conditioning Systems, Division of Building Safety

- Fire Protection:

- National Fire Protection Association (NFPA):

- NFPA 1, Fire Prevention Code 2006 Edition

- NFPA 10, Standard for Portable Fire Extinguishers 2007 Edition

- NFPA 13, Standard for the Installation of Sprinkler Systems 2007 Edition

- NFPA 14, Standard for the Installation of Standpipe, Private Hydrant, and Hose Systems 2007 Edition

- NFPA 15, Standard for Water Spray Fixed Systems for Fire Protection 2007 Edition

- NFPA 16, Standard for the Installation of Foam-Water Sprinkler and Foam-Water Spray Systems 2007 Edition

- NFPA 17, Standard for Dry Chemical Extinguishing Systems 2002 Edition

- NFPA 18A, Standard on Water Additives for Fire Control and Vapor Mitigation 2007 Edition

- NFPA 20, Standard for the Installation of Stationary Pumps for Fire Protection 1999 Edition

- NFPA 22, Standard for Water Tanks for Private Fire Protection 2008 Edition

- NFPA 24, Standard for the Installation of Private Fire Service Mains and Their Appurtenances 2007 Edition

- NFPA 30, Flammable and Combustible Liquids Code 2008 Edition 
- NFPA 37, Standard for the Installation and Use of Stationary Combustion Engines and Gas Turbines 2006 Edition

- NFPA 45, Standard on Fire Protection for Laboratories Using Chemicals 2004 Edition

- NFPA 50, Standard for Bulk Oxygen Systems at Consumer Sites 2001 Edition

- NFPA 51, Standard for the Design and Installation of Oxygen-Fuel Gas Systems for Welding, Cutting, and Allied Processes 2007 Edition

- NFPA 53, Recommended Practice on Materials, Equipment, and Systems Used in OxygenEnriched Atmospheres 2004 Edition

- NFPA 54, National Fuel Gas Code 2006 Edition

- NFPA 55, Standard for the Storage, Use, and Handling of Compressed Gasses and Cryogenic Fluids in Portable and Stationary Containers, and Tanks 2005 Edition

- NFPA 57, Liquefied Natural Gas (LNG) Vehicular Fuel Systems Code 2002 Edition

- NFPA 59A, Standard for the Production, Storage, and Handling of Liquefied Natural Gas (LNG) 2006 Edition

- NFPA 68, Guide for Venting of Deflagrations 2007 Edition

- NFPA 69, Standard on Explosion Prevention Systems 2008 Edition

- NFPA 70, National Electrical Code 2008 Edition

- NFPA 70E, Standard for Electrical Safety Requirements for Employee Workplaces 2004 Edition

- NFPA 72, National Fire Alarm Code 2007 Edition

- NFPA 75, Standard for the Protection of Electronic Computer/Data Processing Equipment 2003 Edition

- NFPA 77, Recommended Practice on Static Electricity 2007 Edition

- NFPA 79, Electrical Standard for Industrial Machinery 2007 Edition

- NFPA 80, Standard for Fire Doors and Fire Windows 2007 Edition

- NFPA 80A, Recommended Practice for Protection of Buildings from Exterior Fire Exposures 2007 Edition

- NFPA 85, Boiler and Combustion Systems Hazards Code 2007 Edition

- NFPA 86, Standard for Ovens and Furnaces 2007 Edition

- NFPA 90A, Standard for the Installation of Air-Conditioning and Ventilating Systems 2002 Edition

- $\quad$ NFPA 90B, Standard for the Installation of Warm Air Heating and Air-Conditioning Systems 2006 Edition

- $\quad$ NFPA 91, Standard for Exhaust Systems for Air Conveying of Vapors, Gases, Mists, and Noncombustible Particulate Solids 2004 Edition

- NFPA 96, Standard for Ventilation Control and Fire Protection of Commercial Cooking Operations 2008 Edition

- NFPA 101, Life Safety Code 2006 Editions

- NFPA 105, Standard for the Installation of Smoke Door Assemblies 2007 Edition

- NFPA 110, Standard for Emergency and Standby Power Systems 2005 Edition

- NFPA 111, Standard on Stored Electrical Energy Emergency and Standby Power Systems 2005 Edition 
- NFPA 170, Standard for Fire Safety Symbols 2006 Edition

- NFPA 214, Standard on Water-Cooling Towers 2005 Edition

- NFPA 220, Standard on Types of Building Construction 2006 Edition

- NFPA 221, Standard for Fire Walls and Fire Barrier Walls 2006 Edition

- NFPA 232, Standard for the Protection of Records 2007 Edition

- NFPA 262, Standard Method of Test for Flame Travel and Smoke of Wires and Cables for Use in Air-Handling Spaces 2007 Edition

- NFPA 430, Code for the Storage of Liquid and Solid Oxidizers 2004 Edition

- NFPA 496, Standard for Purged and Pressurized Enclosures for Electrical Equipment 2008 Edition

- NFPA 497, Recommended Practice for the Classification of Flammable Liquids, Gases, or Vapors and of Hazardous (Classified) Locations for Electrical Installations in Chemical Process Areas 2008 Edition

- NFPA 499, Recommended Practice for the Classification of Combustible Dusts and of Hazardous (Classified) Locations for Electrical Installations in Chemical Process Areas 2008 Edition

- NFPA 750, Standard on Water Mist Fire Protection Systems 2006 Edition

- NFPA 780, Standard for the Installation of Lightning Protection Systems 2008 Edition

- NFPA 820, Standard for Fire Protection in Wastewater Treatment and Collection Facilities 2008 Edition

- NFPA 2001, Standard on Clean Agent Fire Extinguishing Systems 2008 Edition

- NFPA 2010, Standard for Fixed Aerosol Fire-Extinguishing Systems 2006 Edition.

- Electrical:

- General Facility Electrical Codes and Standards:

- NFPA 70, National Electric Code (NEC)

- NFPA 70E, Electrical Safety Requirements for Employee Workplaces

- IEEE-C2, National Electrical Safety Code

- DOE-HDBK-O 420.1, DOE Handbook, Design Considerations

- DOE-HDBK-1092, DOE Handbook, Electrical Safety

- DOE-HDBK-1132, DOE Handbook, Design Considerations

- Normal Power System Codes and Standards:

- IEEE-STD 141, IEEE Recommended Practice for Electric Power Distribution for Industrial Plants, Red Book

- NFPA 79, Electrical Standard for Industrial Machinery

- IEEE-STD 242, IEEE Recommended Practice for Protection and Coordination of Industrial and Commercial Power, Buff Book

- IEEE-STD 493, IEEE Recommended Practice for the Design of Reliable Industrial and Commercial Power Systems, Gold Book

- UL-508A, Industrial Control Equipment 
- International Electrical Testing Association-ATS, International Electrical Testing Association, Acceptance Testing Specifications for Electrical Power Distribution Equipment and Systems

- Standby Power System Codes and Standards:

- IEEE-STD 446, IEEE Recommended Practice for Emergency and Standby Power Systems for Industrial and Commercial Applications, Orange Book

- IEEE-STD 519, IEEE Recommended Practice and Requirements for the Harmonic Control in Electrical Power Systems

- IEEE-STD 141, IEEE Recommended Practice for Electric Power Distribution for Industrial Plants, Red Book

- IEEE-STD 242, IEEE Recommended Practice for Protection and Coordination of Industrial and Commercial Power, Buff Book

- NFPA 110, Emergency and Standby Power Systems

- NFPA 111, Stored Electrical Energy Emergency and Standby Power Systems

- Uninterruptible Power Supply System Codes and Standards:

- DOE-SPEC-3021, Uninterruptible Power Supply (UPS) Systems

- IEEE-944, IEEE recommended practice for the application and testing of Uninterruptible Power Supplies for Power Generating Stations

- NEMA PE 1, Uninterruptible Power Systems - Specification and Performance Verification

- $\quad$ Lighting System Codes and Standards:

- 40 CFR 261.24, EPA Toxicity Characteristic Leaching Procedure (TCLP)

- NFPA 101, Life Safety Code

- IES, Lighting Handbook

- ASHRAE 90.1, Energy Standard for Buildings

- Grounding System Codes and Standards:

- IEEE-80, IEEE Guide for Safety in AC Substation Grounding

- IEEE-STD 142, IEEE Recommended Practice for Grounding of Industrial and Commercial Power Systems, Green Book

- IEEE-1050, IEEE Guide for Instrumentation and Control Equipment Grounding in Generating Stations

- IEEE-1 100, Recommended Practice for Powering and Grounding Sensitive Electronic Equipment Emerald Book

- NFPA 77, Recommended Practice on Static Electricity

- Lightning Protection System Codes and Standards:

- NFPA 780, Lightning Protection Code

- UL-96A, Installation Requirements for Lightning Protection Systems

- Telephone System Codes and Standards:

- ANSI/TIA/EIA 568 B.1, Commercial Building Telecommunications Cabling Standard Part 1: General Requirements

- ANSI/TIA/EIA 568 B.2, Commercial Building Telecommunications Cabling Standard Part 2: Balanced Twisted Pair Cabling Components 
- ANSI/TIA/EIA 568 B.3, Optical Fiber Cabling Components Standard

- ANSI/TIA/EIA 569 A, Commercial Building Standards for Telecommunications Pathways and Spaces

- ANSI/TIA/EIA 607, Commercial Building Grounding and Bonding Requirements for Telecommunications

- Instrumentation and Controls:

- $\quad$ DOE-STD-1039, Guide to Good Practices for Control of Equipment and System Status

- ISA 5.1, Instrumentation Symbols and Identification

- $\quad$ ISA 5.3, Graphic Symbols for Distributed Control/Shared Display Instrumentation, Logic and Computer Systems

- ISA 5.4, Instrument Loop Diagrams

- ISA 5.5, Graphic Symbols for Process Displays

- ISA 18.2, Management of Alarm Systems

- IEEE-1050, IEEE Guide for Instrumentation and Control Equipment Grounding in Generating Stations

- IEEE-1046, Application Guide for Distributed Digital Control and Monitoring for Power Plants

- UL-1998, UL Standard for Safety for Software in Programmable Components

- $\quad$ IEC 61508, Functional Safety - Safety Related Systems

- $\quad$ ANSI/ISA 84.00.01, Functional Safety - Safety Instrumented Systems (SIS) for Process Industry Sector

- ANSI B11-19, American National Standard for Machine Tools - Safeguarding when referenced by the other B11 Machine Tool Safety Standards - Performance Criteria for Design, Construction, Care, and Operation

- IEEE-C37.96, IEEE Guide for AC Motor Protection

- UL-1998-1998, UL Standard for Safety for Software in Programmable Components

- NEMA ICS Series, Industrial Control and System Standards

- NEMA MG-2, Safety Standard for Construction and Guide for Selection, Installation, and Use of Electric Motors

- IEEE-1046, Application Guide for Safety for Software in Programmable Components

- IEEE-1100, Recommended Practice for Powering and Grounding Sensitive Electron Equipment Emerald Book

\section{TEST LOOP DESIGN CODE OF RECORD}

Codes of Record for the Test loop design are as follows:

- General Design:

- IBC, International Building Code 2009 Edition

- $\quad$ NFPA 101, Life Safety Code 2009 Edition

- IFC, International Fire Code 2009 Edition

- IMC, International Mechanical Code 2009 Edition

- NFPA 70, National Electric Code (NEC)

- *INL-STD-139, INL Engineering Standards

- Structural: 
- $\quad$ DOE O 420.1B, Facility Safety

- DOE-STD-1020, Natural Phenomena Hazards Design and Evaluation Criteria for Department of Energy Facilities

- *INL Welding Manual

- Aluminum Design Manual, The Aluminum Association 2005 Edition

- $\quad$ ASCE 7, Minimum Design Loads for Buildings and Other Structures, American Society of Civil Engineers 2005 Edition

- $\quad$ AISC SCM, Steel Construction Manual, American Institute of Steel Construction $13^{\text {th }}$ Edition

- $\quad$ AWS D1.1, Structural Welding Code - Steel, American Welding Society 2004 Edition

- $\quad$ AWS D1.3, Structural Welding Code - Sheet Steel, American Welding Society 1998 Edition

- $\quad$ ASCE 8, Standard Specification for the Design of Cold-formed Stainless Steel Structural Members, American Society of Civil Engineers 2002 Edition

- $\quad$ AISI S100-S214, North American Specification for the Design of Cold-formed Steel Structural Members, American Iron and Steel Institute 2007 Edition

- Mechanical, Piping and Vessels:

- ASME B31.1, Power Piping, American Society of Mechanical Engineers 2007 Edition

- ASME B31.3, Process Piping, American Society of Mechanical Engineers 2008 Edition

- $\quad$ BPVC, Section I, Boiler Pressure Vessel Code - Power Boilers, American Society of Mechanical Engineers 2007 Edition

- $\quad$ BPVC, Section II, Boiler Pressure Vessel Code - Materials, American Society of Mechanical Engineers 2007 Edition

- $\quad$ BPVC, Section IV, Boiler Pressure Vessel Code - Heating Boilers, American Society of Mechanical Engineers 2007 Edition

- BPVC, Section V, Boiler Pressure Vessel Code - Nondestructive Examination, American Society of Mechanical Engineers 2007 Edition

- $\quad$ BPVC, Section VIII, Boiler Pressure Vessel Code - Pressure Vessels, American Society of Mechanical Engineers 2007 Edition

- Fire Protection:

- $\quad$ National Fire Protection Association (NFPA)

- NFPA 1, Fire Prevention Code 2006 Edition

- NFPA 10, Standard for Portable Fire Extinguishers 2007 Edition

- NFPA 30, Flammable and Combustible Liquids Code 2008 Edition

- NFPA 55, Standard for the Storage, Use, and Handling of Compressed Gasses and Cryogenic Fluids in Portable and Stationary Containers, and Tanks 2005 Edition

- NFPA 59A, Standard for the Production, Storage, and Handling of Liquefied Natural Gas (LNG) 2006 Edition

- NFPA 68, Guide for Venting of Deflagrations 2007 Edition

- NFPA 69, Standard on Explosion Prevention Systems 2008 Edition

- NFPA 70, National Electrical Code 2008 Edition

- $\quad$ NFPA 70E, Standard for Electrical Safety Requirements for Employee Workplaces 2004 Edition

- NFPA 72, National Fire Alarm Code 2007 Edition 
- NFPA 77, Recommended Practice on Static Electricity 2007 Edition

- NFPA 79, Electrical Standard for Industrial Machinery 2007 Edition

- NFPA 91, Standard for Exhaust Systems for Air Conveying of Vapors, Gases, Mists, and Noncombustible Particulate Solids 2004 Edition

- NFPA 101, Life Safety Code 2006 Editions

- NFPA 105, Standard for the Installation of Smoke Door Assemblies 2007 Edition

- NFPA 110, Standard for Emergency and Standby Power Systems 2005 Edition

- NFPA 111, Standard on Stored Electrical Energy Emergency and Standby Power Systems 2005 Edition

- $\quad$ NFPA 170, Standard for Fire Safety Symbols 2006 Edition

- Electrical:

- $\quad$ NFPA 70, National Electric Code (NEC)

- $\quad$ NFPA 70E, Electrical Safety Requirements for Employee Workplaces

- DOE-HDBK-1092, DOE Handbook, Electrical Safety

- UL-508, Industrial Control Equipment

- IEEE-1100, Recommended Practice for Powering and Grounding Sensitive Electronic Equipment Emerald Book

- $\quad$ NFPA 77, Recommended Practice on Static Electricity

- $\quad$ ANSI/TIA/EIA 568 B.3, Optical Fiber Cabling Components Standard

- Instrumentation and Controls:

- DOE-STD-1039, Guide to Good Practices for Control of Equipment and System Status

- ISA S5.1, Instrumentation Symbols and Identification

- ISA S5.3, Graphic Symbols for Distributed Control/Shared Display Instrumentation, Logic and Computer Systems

- ISA S5.4, Instrument Loop Diagrams

- ISA S5.5, Graphic Symbols for Process Displays

- IEEE-1050, IEEE Guide for Instrumentation and Control Equipment Grounding in Generating Stations

- IEEE-1046, Application Guide for Distributed Digital Control and Monitoring for Power Plants

- UL-1998, UL Standard for Safety for Software in Programmable Components

- $\quad$ IEC 61508, Functional Safety - Safety Related Systems

- $\quad$ ANSI/ISA 84.00.01, Functional Safety - Safety Instrumented Systems (SIS) for Process Industry Sector

- IEEE-1100, Recommended Practice for Powering and Grounding Sensitive Electron Equipment Emerald Book.

\section{REQUIREMENTS BY PLANTWIDE SYSTEM}

Table 1 shows the codes and requirements applicable by plantwide system broken down by work breakdown structure format. Individual system requirements will be identified in the future system design descriptions. 


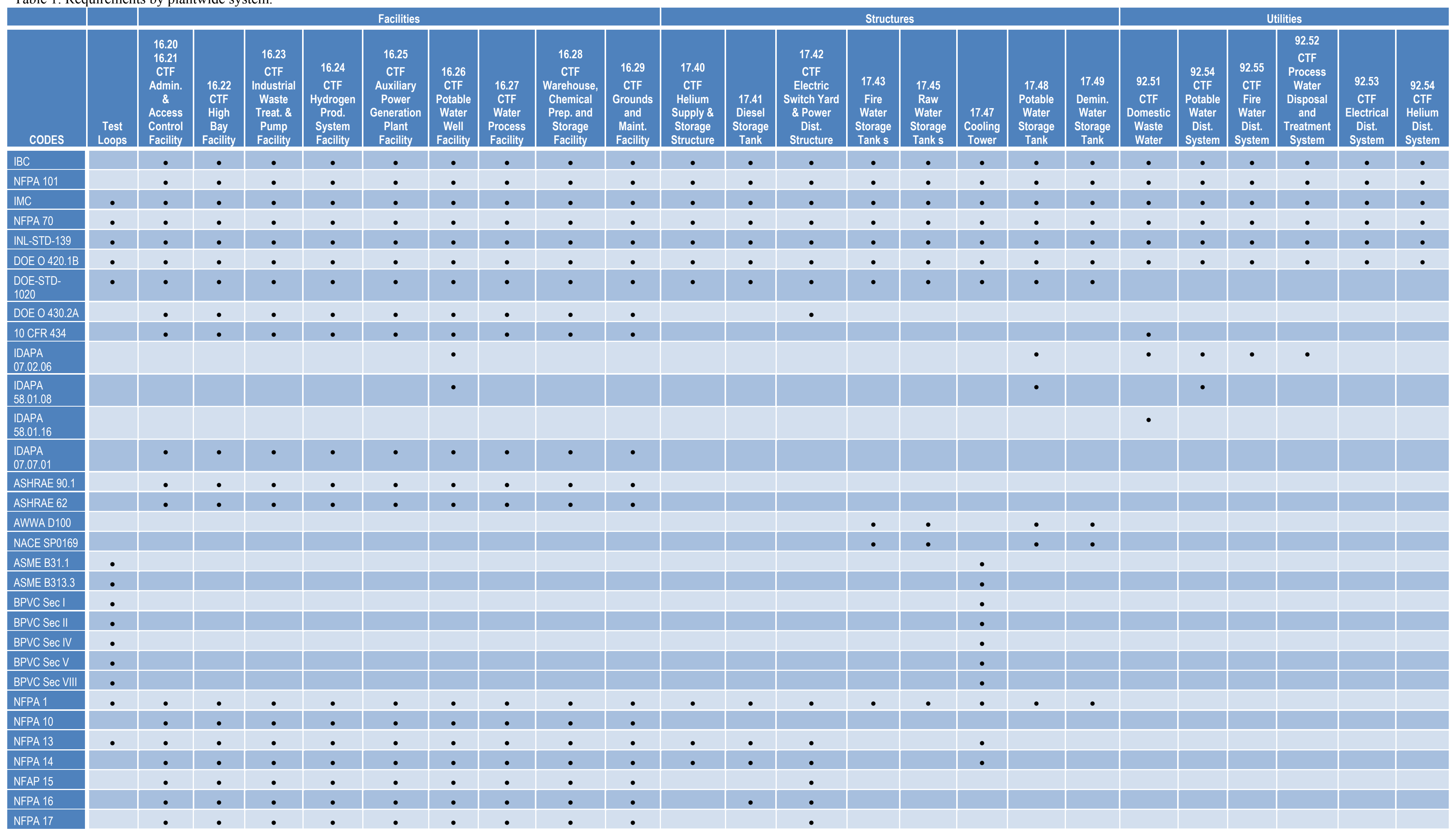




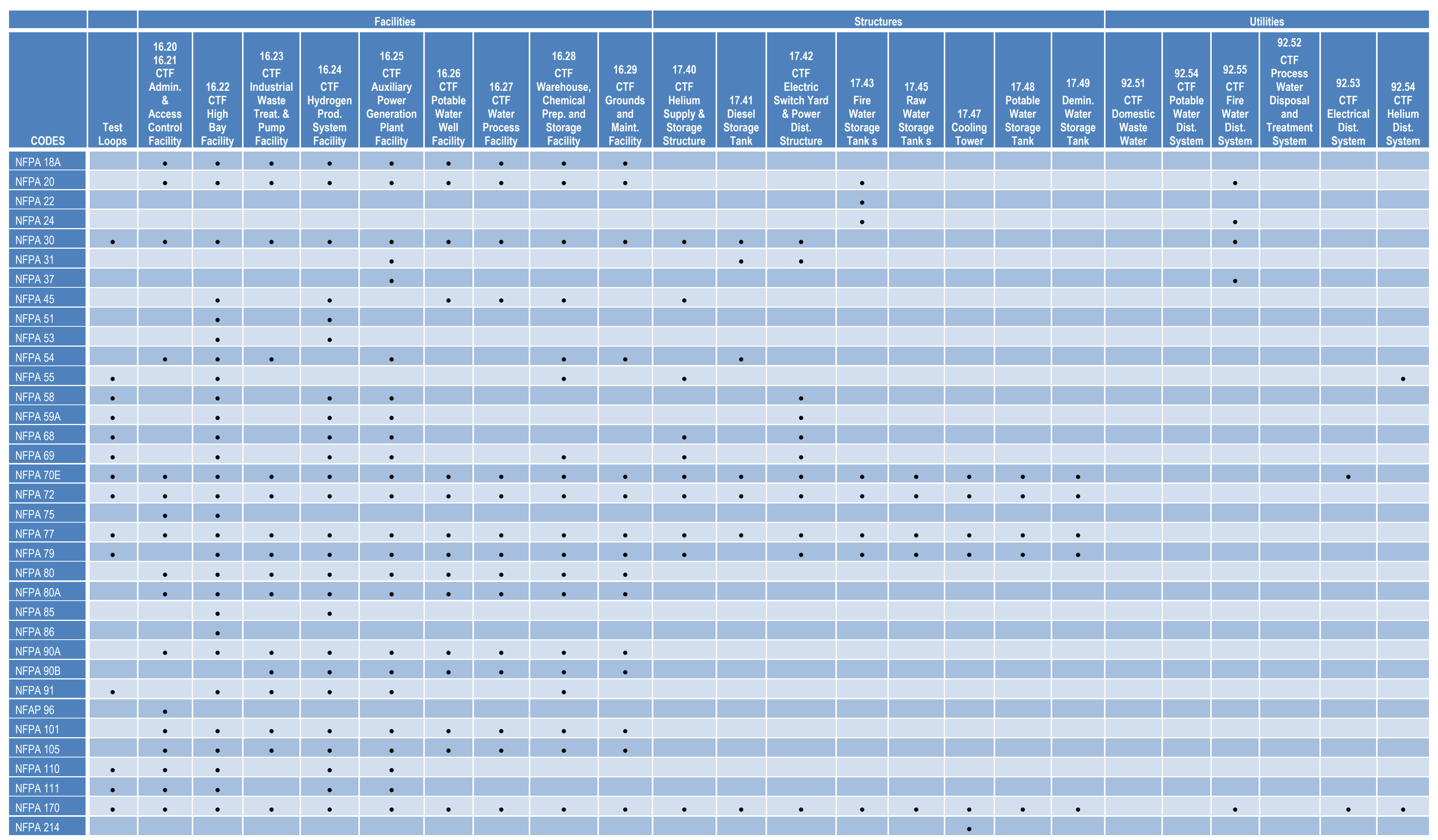




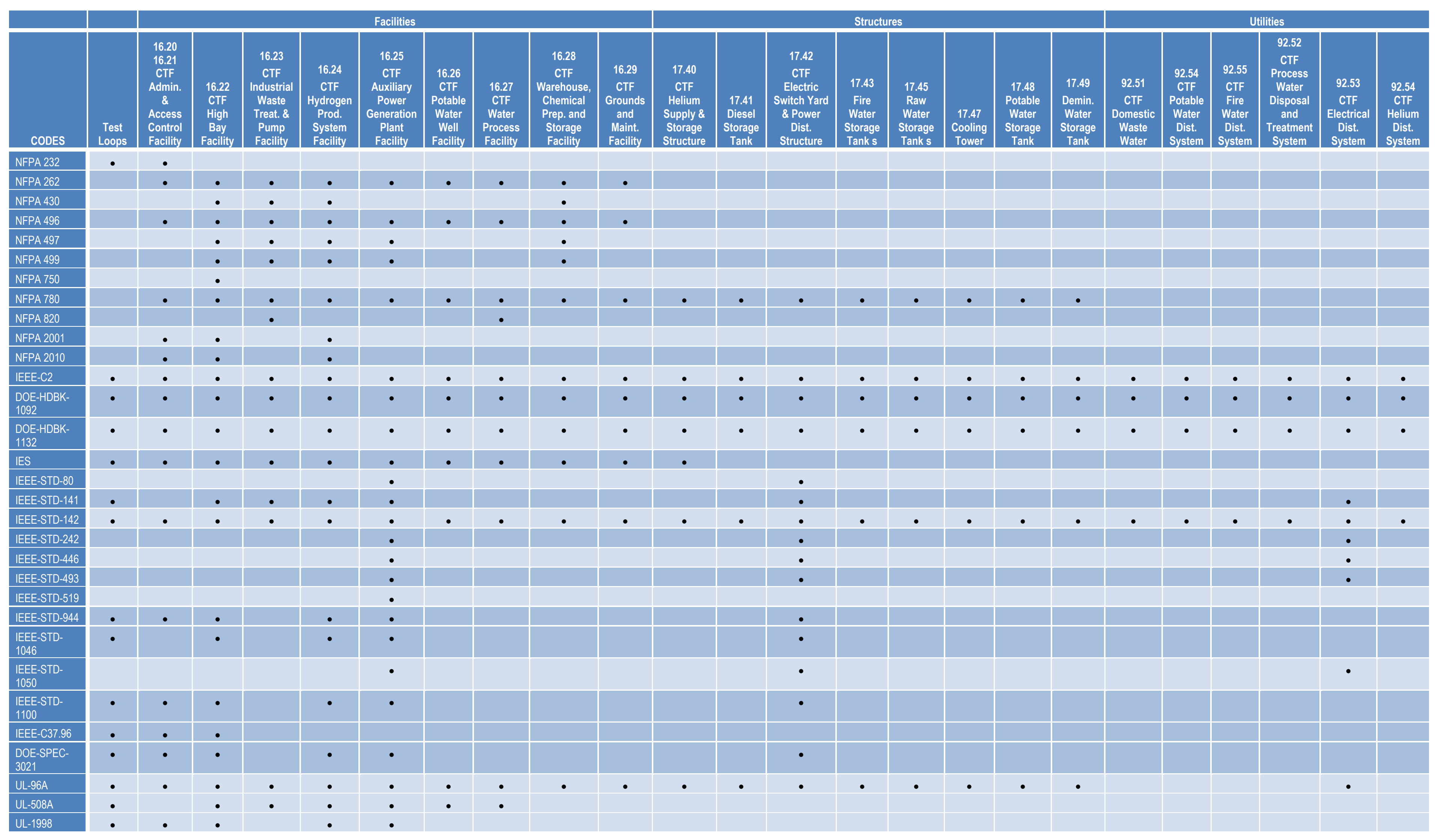




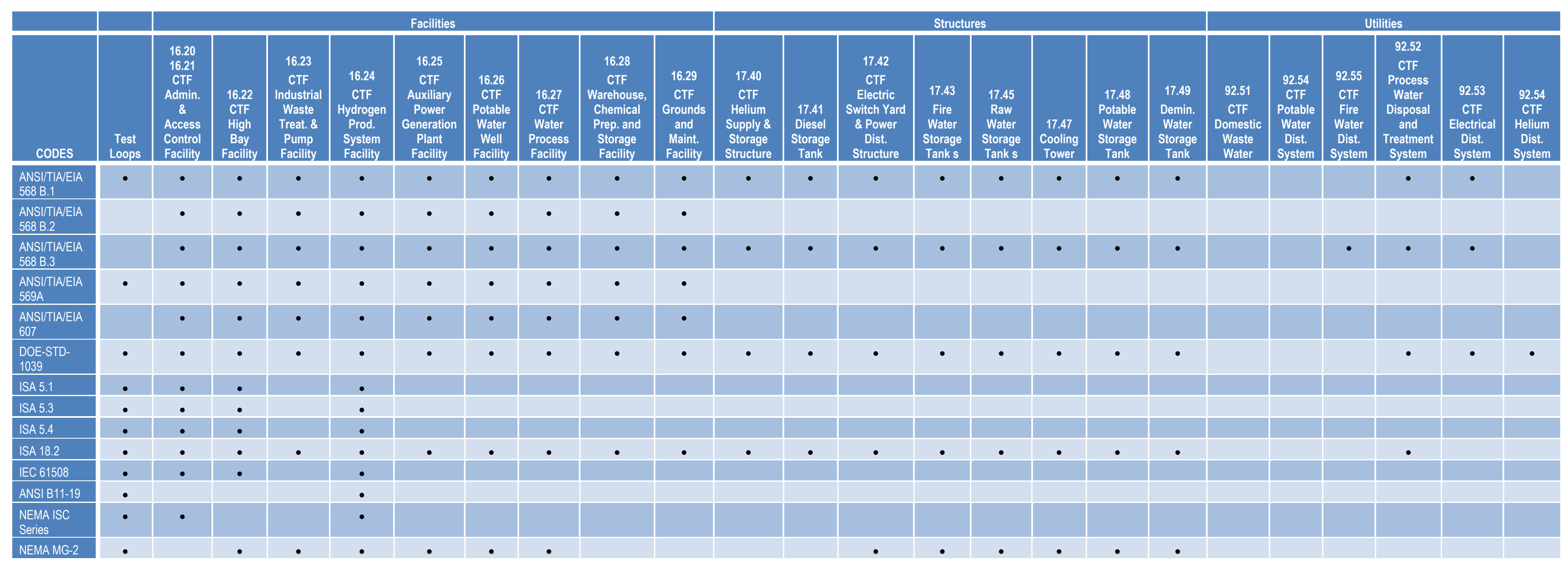

